Ajankohtaiset

Juhlaessee Helmi Järviluoma-Mäkelän 60-vuotispäivän kunniaksi

\title{
Kuvitellut, keksityt, löydetyt
}

\author{
Pohdintoja perinteen subjektin vaiheilta
}

\author{
Seppo Knuuttila
}

$\mathrm{V}$

arttuneille tieteenharjoittajille omistetuissa kollegiaalisissa kirjoituksissa on tapana silmäillä niitä vuosikymmeniä, joiden aikana heidän tieteenalansa ovat edistyneet. Usein päähenkilöt ovat itsekin olleet aktiivisia uudistajia. He ovat löytäneet ja keksineet uusia tutkimusaiheita sekä vahvistaneet osaltaan sellaisia näkökulmia, jotka ovat vakiintuneet omiksi aloikseen. Hyvä esimerkki tällaisesta on Helmi Järviluoma-Mäkelän kollegoineen Suomessa aloittama ja kehittämä äänimaisemien tutkimus (ks. esim. Järviluoma-Mäkelä \& al. 2006). Nykyään sillä on omat koordinaattinsa monitieteisen kulttuurintutkimuksen kentällä. Ja jos ei olisi, joku ne kyllä keksisi.

Kun kulttuurintutkimus teki tuloa meillekin 1980-luvulla, sen tutkimuskohteita alettiin tarkastella "annettuna otetun" sijasta erilaisina konstruktioina. Esimerkiksi perinnetieteiden kansa osoitettiin monin sanoin tutkijoiden työpöydillä laadituksi artikulaatioksi. Tosin kysymys perinteen subjektista oli kyllä jakanut aiemminkin folkloristeja eri leireihin: jotkut olivat sitä mieltä, että folklore on kollektiivisen luomisprosessin ilmentymä, kun taas yksilöpainotteisesta näkökulmasta kollektiivisesti luotua runoutta pidettiin mahdottomana. Nämä vastakkaisuudet alkoivat kulttuuristen käänteiden keskusteluissa näyttää vähitellen enemmänkin toisiaan tukevilta kuin pois sulkevilta. Kysymys ei ollut niinkään laihasta sovusta kuin tieto-opillisten painotusten muutoksista, uusista tutkimusasetelmista ja -kohteista, menneen uusista lukutavoista sekä monista muista kiistanalaisuuksista.

Tarkastelen seuraavassa eräiden tutkimustekstien valossa sitä, miten tieteellis-taiteellinen mosaiikki anonyymista kansasta on viime vuosikymmeninä tarkentunut, miten siirtymät kollektiivisubjektin konstruktiosta yksilöiden repertoaareihin ja artikulaatioihin ovat rikastuttaneet mahdollista ymmärrystämme kulttuuriperinnön moniaineksisuudesta. Esimerkkitekstit käyvät yli vuosikymmenten ja sukupolvien ulottuvaa keskustelua toistensa kanssa niin, että voimme nähdä, miten vaikkapa erilaiset subjektien tulkinnat orastavat, tulevat vallitseviksi ja haastetaan uudelleen. 


\section{Merkitysten konstruointi}

Otaksun otsikkoni tuovan kulttuurintutkimuksen vaiheita seuranneen lukijan mieleen Benedict Andersonin kuviteltujen yhteisöjen käsitteen sekä Eric Hobsbawmin (ja Terrence Rangerin) idean keksityistä ja/tai löydetyistä perinteistä. Molemmat runsasversioiset sanaparit palautuvat vuonna1983 ilmestyneisiin teoksiin, joissa eri tavoin ja erilaisin painotuksin tarkasteltiin nationalismin konstruktioita ja diskursseja. Sekä Anderson että Hobsbawm ovat myöhemmin valitelleet sitä, että mainitut käsitteet ovat ylenpalttisesti toistettuina leimanneet heidän tutkijanuraansa ja jättäneet varjoon muita laaja-alaisia tärkeitä teemoja.

Kuviteltujen ja keksittyjen todellisuuksien käsitteet ovat jouduttaneet kulttuurintutkimuksen tieto-opillisia käänteitä ja kantaneet viestiä uudenlaisten lähestymistapojen mahdollisuuksista. Itseäni näissä Andersonin ja Hobsbawmin teksteissä, joita olen lukenut eri näkökulmista neljällä vuosikymmenellä, on kiinnostanut eritoten se, miten niiden tulkitsema kollektiivinen tietoisuus projisoituu erinäisiin historian ja perinteen tulkintoihin vuosituhannen vaihteen molemmin puolin.

Historiatieteiden ja -taiteiden aloilla elämäkerrallinen tutkimus on lipunut jo vuosisatoja valtavirrassa. Suurmiehet, sotapäälliköt, diktaattorit, nerot ja muut henkilöitymät ovat niin tekstuaalisesti kuin visuaalisestikin saaneet edustuksensa kansakuntien soihdunkantajina. Varsinkin taitelijaelämäkerroissa erilaiset fiktion ulottuvuudet ovat ottaneet tilaa perinteisiltä, todenmukaisiksi otaksutuilta esityksiltä.

Löytämisestä ja keksimisestä puheen ollen antropologi Roy Wagner oli jo aiemmin (1975) esittänyt, että kulttuureja koskevat tutkimukset ja muut representaatiot ovat yhtä vähän suoria kohteen kuvauksia kuin maalaus siitä mitä se esittää. Jokainen kukkaketoa esittävä taideteos muistuttaa enemmän kaikkia toisia taideteoksia kuin kukkaketoa. Wagnerin kirjan nimi oli aikanaan haastavasti The Invention of Culture, ja siitäkin lähti osaltaan liikkeelle keskustelu, jossa dekonstruoitiin kulttuuristen ilmiöiden keksimisen ja osittain myös löytämisen "kulttuurihistoriaa". Wagnerin (uus)tulkintojen keskiössä olivat lyhyesti sanottuna merkitykset, jotka välittävät esityksen ja esitetyn suhdetta (esimerkiksi myyttianalyysissa niin, että molemmat ulottuvuudet ovat myytissä itsessään läsnä eikä viittauksia muihin mahdollisiin maailmoihin tarvita).

Parikymmentä vuotta sitten tieteenfilosofi lan Hacking kiinnitti (1999) huomiota siihen, miten erityisesti sosiaalisen konstruktionismin piirissä on pohdittu menneisyyden rekonstruointia sekä keksittyinä että löydettyinä ilmiöinä. Hän muun muassa viittaa kahteen samannimiseen kirjaan Inventing Women, joista toinen käsittelee naiskeksijöitä ja toinen sitä, miten luonnontieteissä on keksitty rooleja naisille. Viime vuosikymmenen lopulla koko moderni maailma alkoi näyttää läpeensä keksityltä; lukuisten "inventing something" -kirjojen tiheää julkaisemista Hacking kutsuu 1990-luvun alun keksintöorgioiksi, jotka "järjestettiin sellaisille inmisille, joiden mielestä idea kansakunnasta tai alueesta X kaikkine fiktiivisine ja stereotyyppisine konnotaatioineen on melko väistämätön." Ehkä Anderson ja Hobsbawnkin pistäytyivät noissa bileissä.

Kulttuuristen käänteiden tältä puolen katsoen perinteentaitaja ja -kannattaja on kulttuuritieteissä ollut autenttiseksi kirjoitettu konstruktio, diskursiivinen muodostuma ja artikulaatio, jonka luojaksi ja tarkastelijaksi sen sepittänyt auktori, eräänlainen näkymätön subjekti 
asettuu. Kehystän pohdintaani subjektin vaiheilta vielä niinkin, että jäsentelen ja kommentoin eräitä folkloristiikan ja lähialojen subjektikokeiluja - niin sanoakseni - ennen postmodernin hajottavaa vaikutusta. Ja miten niitä kulttuurisiin käänteisiin osallistuneiden väitöskirjojen valossa voidaan lukea vastakarvaan.

Mikko Lehtosen väitöskirja Kyklooppi ja kojootti. Subjekti 1600-1900-lukujen kulttuuri ja kirjallisuusteorioissa (1994) on kiinnostava aikalaisdokumentti niistä keskusteluista, jotka kulttuuristen käänteiden ristiaallokossa olivat pinnalla ja kiistanalaisia. Siinä kyklooppi tarkoittaa tutkittavasta erillään olevaa, aktiivista toimijaa, jonka paikaltaan tarkastelema objekti, patsas, on sekä passiivinen olio että tarkastelun tulos. Kun taas nomadin ja kojootin toiminnassa korostuvat subjektin ja objektin vuorovaikutus, paikanvaihdon mahdollisuus, tiedon monitulkintaisuus ja paikantuneisuus. Kyklooppia ja kojoottia saatteli subjektia pohtivien keskustelujen laajentuminen, tulkintojen rönsyilyä yli tieteenalarajojen sekä uusien merkityspotentiaalien etsiskelyä ja pohdintaa. Jälkeenpäin ajatellen erityisen kiinnostava kysymys oli, missä määrin kyklooppinen tiedonintressi on todella rajoittunut modernin yksisilmäiseen rationaliteettiin ja itselleen sokeaan objektiivisuuteen. Lehtonen kyllä lopuksi muistuttaa, että kykloopin diskurssi on edelleen, siis tuolloin, hallitsevassa asemassa, mutta vieläkin voidaan kysyä, kuten Erkki Vainikkala aikanaan Lehtosen väitöskirjasta kirjoittaessaan, millainen varjo kykloopin tieto-opista nykyisyyden ylle lankeaa?

\section{Folkloristin kekseliäisyys ja subjektien siirtymät}

Olen koko aikuiselämäni inmetellyt ja ihaillut kansanrunoudentutkija Matti Kuusen teoreettista ja menetelmällistä individualismia, jälkimodernin termiä käyttääkseni multimodaalisuutta, jolla hän konstruoi sekä kalevalamittaisen runouden laajoja tyylikausia että yksittäisiä laulajaprofiileja. Vaikka noiden tyylikausien historiallisia kytkentöjä on jo pitkään epäilty, niiden kuvitteelliset ja mahdolliset artikulaatiot kaikuvat edelleen folkloristiikan metsänrajassa.

Kuusi myöntää auliisti, että hänen kuvittelemansa kansanrunouden laulaja-lauluntekijä Lintuelegikko on Priaamelihumoristin ja Turkulaismodernistin tapaan "vain kuvitelma, auditiivinen fiktio, heleä neidonääni vuosisatojen takaa." "Mutta", paradoksien mestari jatkaa, "kuvitelmaa eivät ole hänen runonsa." Ja niin Kuusi ajoittaa tyylikriteerien perusteella yhteen saattamansa runot 13. tai 14. vuosisadan Karjalaan. Ja tarjoaa vielä pari kritiikille altista lausetta: "Tuntematon karjalaisneito ei ollut ensimmäinen eikä viimeinen surujensa soitoksi jalostaja, mutta - sanoisin - kaikista suomalaisista lyyrikoista hän oli kantelettarelaisin. Pidän hänen äänestään. Se on minulle yhtäläinen symboli kuin erämaan hiekasta paljastuva Afroditen patsas arkeologille." Kyllähän tästä avautuu aineksia keksityn subjektin pohtijalle niin kykloopin kuin Pygmalioninkin suuntaan. Ongelmallisinta tässä on ollut ehkä se, että fiktiivisen subjektin korostus on varjostanut runojen tyylianalyysia, mihin taas kritiikki on suuntautunut huomattavasti rakentavammin, myös kirjallisuuden tutkimuksen suunnalta.

Kirjoittaessaan Anni Lehtosen runousopista vuonna 1970 Kuusi oli sitä mieltä, että sellaisten lahjakkaitten perinteentaitajien kuin Anni Lehtonen, Larin Paraske tai "Pertti Virtarannan vuonna 1959 löytämä oulankalainen Marina Takalo" itkuvirret ja lyyriset runot ovat suureksi osaksi "puoli-improvisoitua tilannerunoutta: perinnäisistä kuvista ja säekuvioista perinnäistä sommittelutekniikkaa käyttäen punottua hetken lyriikkaa." Kuusi evästää tulevia tutkijoita etenemään transformaatioteorian suuntaan ja kiinnittämään huomiota siihen, miten esitys 
tuottaa esityksen, miten yksilölliset repertoaarit voivat "luoda perustaa entistä täsmällisemmälle käsitykselle säilyvästä ja muuttuvasta perinteestä".

Siinä missä Kuusi pitää kiinni säetutkimuksen menetelmästä yrittäessään löytää "yksilöllisen profiilin kollektiivitradition takaa", hän Maria Luukka -tutkimuksensa lopussa avaa jo vuoropuhelua Senni Timosen - Kuusen sanoin - ihailtavan, joskin intuitiovaltaisen Larin Paraske -tulkinnan suuntaan. Lupaavaa nimittäin oli, että uudet subjektihahmotelmat sopivat huonosti legendaariseen Larin Paraske -kuvaan. Kuusen kaavailema näkökulman vaihdos ja sen mietintä, miten runoteksteistä olisi pääteltävissä niiden esittäjän profili, on saanut vastauksensa sittemmin useissa kalevalamittaisen runon tuoreissa tutkimuksissa.

Kulttuuristen käänteiden tältä puolen Kuusen kysymykseen on vastannut Senni Timonen väitöskirjassaan (2004). Siinä subjekti avautuu runoteksteistä useaan suuntaan kuten uutta luovaan ja vanhaa toistavaan, emootioita ilmaisevaan esittäjään, muulta tulleeseen runojen kyselijään ja muistiin merkitsijään, nykypäivän tulkitsijaan. Samoin Tarja Kupiainen on tähdentänyt (2004) runojen minän ja esittäjän minän kietoutuvan monin säkein toisiinsa, myös Maria Luukan kohdalla.

Lotte Tarkka puolestaan esittää (2005), Lehtosen runojen seikkaperäisen luennan tuloksena muun muassa, miten Anni Lehtosen ja hänen sisarensa runot paljastavat strategian, jolla vienankarjalaisen naisen elämänkokemusta käsiteltiin. "Omaelämäkerta on itse sepitetty elämä, vaikka sen ainekset ja rajat ovatkin historiallisesti annettuja, äidiltä opittuja - laulajan uskonnollisen vakaumuksen mukaan - Jumalan luomia." (s. 197). Tietyt toistuvat runoteemat konstruoivat kokemuksellisen naissubjektin, joka näyttää lainaavan auliisti äänensä niin yksinäisille, leskille, kaltoin kohdelluille kuin läheisensä menettäneille.

Tiina Seppä on runolaulajien ja perinteenkerääjien yhteistyötä tarkastellessaan (2015) korostanut perinneprosessin dialogisuutta sekä tutkijaa sen kolmantena osapuolena. Kun tekstit syntyvät ja saavat merkityksensä eri osapuolten kohtaamisissa, jokainen on omalla tavallaan myös subjektina läsnä. Seppäkin on saanut Anni Lehtosen ja Samuli Paulaharjun yhteistyötä tarkastellessaan jo mainitsemani terveiset Kuuselta. Mutta sopii kysyä, olisivatko Sepän prosessoimat, liikkuvat subjektipositiot olleet mahdollisia viitisen kymmentä vuotta sitten.

Kun runonlaulajia, itkijöitä ja kanteleensoittajia 1800-luvun lopulla ja seuraavan vuosisadan puolella kutsuttiin esiintymään Kansanvalistusseuran laulujuhlille ja muihin yleisötilaisuuksiin, lähtökohtana usein oli, että muinaisrunojen taitajat esittivät edustavia näytteitä perinteen aarteista. Tässä mimeettisen subjektin roolissa heitä arvostettiin ja kuvattiin yksilöinä, mikä tulee suorastaan superlatiivisella tavalla esiin Martti Haavion teoksessa Viimeiset runonlaulajat (1943). Toistaiseksi viimeiset runonlaulajat on vanhan kaavan mukaan löytänyt ja esitellyt vienankarjalaisen perinnekulttuurin maineikas tuntija ja puolestapuhuja Markku Nieminen. He olivat Santra Remsujeva (1914-2010) ja Jussi Huovinen (1924-2017).

\section{Ihmiset ja tyypilliset poikkeukset}

Perinnettä säilyttävän kollektiivisen subjektin hauraan patsaan rikkoi Juha Pentikäinen uskontoantropologisella tutkimuksellaan Marina Takalon uskonto vuonna 1971. Teos osoittautui monessakin mielessä inspiroivaksi poikkeukseksi lähinnä elämäkerroista tunnistetun yksilötutkimuksen alalla. Pentikäinen kehysti tarkastelunsa aiemmilla kertojamonografioilla 
sekä kulttuurin ja persoonallisuuden vuorovaikutuksen antropologisilla näkökulmilla. Siinä missä päähenkilön ja hänen ympäristönsä uskonnollisuuden ilmenemismuodot olivat tutkimuksen aihe ja kohde, Marina Takalo (1890-1970) oli koko tutkimushankkeen persoonallinen subjekti.

Muistan teoksen ilmestyttyä käydyn vilkasta keskustelua muun muassa siitä, mitä mahdollista annettavaa tutkittavan itse sepittämällä omaelämäkerrallisella runoudella on kansanrunoudentutkimukselle. Näin jälkikäteen tulkiten ja kärjistäen keskustelu lainehti kyklooppisen muotokuvaopin, jolla oli vakaat kannattajansa, ja nomadisten subjektikonstruktioiden välillä. Pentikäisellä oli silmää jälkimmäiselle, mikä tuli kiinnostavasti esiin kyseisen teoksen englanninkielisessä versiossa (1978). Siinä Takalo esitellään kansainväliselle lukijakunnalle lahjakkaana perinteentaitajana ja eksoottisen vienalaiskulttuurin viestintuojana. Vaikka uskontoantropologinen näkökulma on tässäkin versiossa vahvasti mukana, kirjan alaotsikon mukaisesti nyt on kysymys elämänhistoriallisesta tutkimusotteesta. Siinä tutkittava ja häntä haastatellut tutkija ovat molemmat subjektin rooleissa. Antropologian oppihistoriasta tunnetaan useitakin tapauksia, joissa tutkimuksen kohteesta on tullut niin sanotusti kanssatutkija tai itsenäisesti omasta kulttuuristaan kirjoittava tai muuten esiintyvä subjekti.

Pentikäisen Takalo-tutkimuksissa näyttää käyneen sittemmin hieman toisin. Vuonna 2010 hän julkaisi aiheestaan kolmannen monografian, otsikkona oli Marina Takalo. Runonlaulaja ja näkijä. Tässä versiossa, joka on toimitettu enemmänkin tieto- ja muistelmakirjan tyyliin, Pentikäinen kirjoittaa itsensä aiempaa enemmän näkyviin, osaksi prosessia eikä tällä kertaa objektivoi omaa osuuttaan siinä.

Marina Takalon uskonnon ilmestyessä ei vielä puhuttu ainakaan laajemmin mikrohistoriasta, mutta kun tämä historiantutkimuksen suuntaus 1970-luvulla alkoi voimistua, siinä muun ohella korostuivat yksittäisten inmisten sanomiset ja tekemiset erilaisissa paikallisissa ja ajallisissa konteksteissa. Meillä mikrohistorian tunnetuin tulkitsija on ollut Carlo Ginzburg, suureksi osaksi Matti Peltosen ansiosta, joka on laajemminkin esitellyt suomalaiselle lukijakunnalle uusia historian suuntauksia. Ginzburgin artikkeleista toimittamassaan teoksessa Johtolankoja. Kirjoituksia mikrohistoriasta ja historiallisesta metodista (1996) Peltonen selvittää laajahkossa johdannossa kiinnostavasti niitä tieto-opillisia rintamalinjoja, joiden eri puolilla Lehtosen termejä soveltaakseni kykloopit ja nomadit argumentoivat.

Ginzburgin laajan tuotannon maineikas teos on 1500-luvulla eläneen mylläri Menocchion elämää ja maailmankuvaa käsittelevä tutkimus Juusto ja madot. 1500-luvun myllärin maailmankuva (1976 / 2007), jonka kuvaus perustuu inkvisition suorittamiin päähenkilön haastatteluihin. Ginzburg oli itsekin sitä mieltä, että esimerkiksi historiallisen antropologian piiriin sijoitettuna Menocchio-tutkimus ei varmaankaan olisi herättänyt sellaista kritiikkiä, jonka se kohtasi historiantutkijoiden konservatiivisella suunnalla. Paitsi että kyseinen tutkimus on vetävästi kirjoitettu, se on erinomainen esimerkki siitä, miten subjektin painotukset siirtyvät kokonaiskuvasta yksityiskohtiin, juustosta matoihin.

Folkloristiikassa yksilön perimätietoon ja sen luovaan tulkintaan paneutuva tutkimus orasti jo 1960-luvulla ja vahvistui seuraavilla vuosikymmenillä. Omalta opintieltäni muistan, miten pro gradu -tutkielmani yhden lapsen, Leena Heinosen pihaperinteestä (1974) eteni myötätuulessa lisensiaattityöksi. Minkä jälkeen minua ystävällisesti opastettiin etsimään mahdollista väitöskirjaa ajatellen "isompi" aihe. 
Kalevalaseuran vuosikirja Kertojat ja kuulijat (1980) esitteli nimeltä mainiten koko joukon kertojia ja vahvisti osaltaan yksilökeskeisen ja myös elämäkerrallisen näkökulman relevanssia perinteentutkimuksessa. Annikki Kaivola-Bregenhøjn ei tarvinnut enää puolustella lähestymistapaansa, kun hän vuonna 1988 julkaisi tutkimuksen sysmäläisen Juho Oksasen kertomuksista ja kerronnasta. Hyviä esimerkkejä perinteen, yksilön ja yhteisöjen artikulaatioista ovat muiden muassa Tuulikki Kurjen (2002) ja Tuija Saarisen (2003) väitöskirjat. Antoisa kansainvälinen perspektiivi aiheeseen avautuu Ray Cashmanin et al. toimittamasta, yksilön ja perinteen artikulaatioita käsittelevästä artikkelikokoelmasta (2011).

\section{Löytämisen lupaus ja lunastus}

Siinä missä Mikko Lehtonen tarkasteli kulttuuri- ja kirjallisuustieteiden subjekteja koskevien tieto-oppien diakronisia liikkeitä, Helmi Järviluoma-Mäkelä puolestaan omassa väitöskirjassaan (1997) analysoi synkronisin kysymyksenasetteluin yhden pelimanniryhmän yhteisöllisyyden rakentumista, sukupuolen määrittymistä ja erilaisia identiteettiprosesseja. Yhdeksänkymmentäluvun keskusteluille ominaisesti subjektien kuvattiin konstruoituvan erilaisissa vuorovaikutusprosesseissa, jotka puolestaan muodostivat monitulkintaisia merkityskonstellaatioita. Niinpä monesta, tuolloin ajan hermolla olleesta tekstistä kysyttiinkin, olisiko se tullut ymmärretyksi vaikkapa parikymmentä vuotta aiemmin.

Kun folkloristit alkoivat tehdä teksteissään tilaa nimeltä mainituille, "verta ja lihaa" olleille/ oleville, persoonallisille tutkimuskohteille sekä enenevässä määrin kirjoittaa myös itseään mukaan tutkimusprosesseihin, nämä valinnat osiltaan ilmenivät tutkimusten uusina lähestymis- ja lukutapoina. Ne rikastuttivat tieteidenvälisiä keskusteluja ja nostattivat myös kritiikkiä, totta kai. Kaikki tämä oli osa sitä humanististen ja yhteiskunnallisten tieteiden käännettä, jonka myötä monet uudet tutkimusalatkin vahvistuivat ja löysivät - tai raivasivat - paikkansa.

Kulttuurintutkimuksessa vaihdettavien näkökulmien ja moniäänisyyden prosessia ovat vahvistaneet aistikokemusten sekä niiden esittämisen ja muistamisen tutkijat. Äänimaiseman tutkimus on meilläkin solahtanut - Helmin sanoin "kuin saukko penkalta Pielisjokeen" osaksi monitieteistä ja -taiteista kulttuurintutkimusta. Senkin monialaisia tuloksia voidaan lukea menneisyyttä rikastuttavina ja nykyajan tulkintoja laajentavina. Vaikka anakronismia syystäkin pidetään lukutapavirheenä, joka vaanii menneen nykyisyyteen siirtäjää, niin voi se olla myös lukutapaohje, kunhan Juha Sihvolan sanoin "ymmärtää, mitä on tekemässä". Tunnen suoranaista voitonriemua voidessani kirjoittaa nämä tosiasiat nyt, vuonna 2020, tähän.

\section{Kirjallisuus}

Anderson, Benedict. 1983. Imagined Communities: Reflections on the Origin and Spread of Nationalism. London: Verso.

Cashman, Ray, Tom Moud ja Pravina Shukla (toim.). 2011. The Individual and Tradition. Folkloristic Perspectives. Bloomington: Indiana University Press.

Ginzburg, Carlo. 1996. Johtolankoja. Kirjoituksia mikrohistoriasta ja historiallisesta metodista. Esipuhe Matti Peltonen. Helsinki: Gaudeamus. 
Ginzburg, Carlo. 2007 (1976). Juusto ja madot. 1500-luvun myllärin maailmankuva. Helsinki: Gaudeamus.

Hacking, lan. 2009 (1999). Mitä sosiaalinen konstruktionismi on? Tampere: Vastapaino.

Hobsbawm, Eric and Terence Ranger. 1983. The Invention of Tradition. Cambridge: Cambridge University Press.

Järviluoma, Helmi. 1977. Musiikki, identiteetti ja ruohonjuuritaso. Amatöörimuusikkoryhmän kategoriatyöskentelyn analyysi. Tampere: Acta Universitatis Tamperensis 555.

Kaivola-Bregenhøj, Annikki. 1988. Kertomus ja kerronta. Helsinki: SKS.

Kupiainen, Tarja. 2004. Kertovan kansanrunouden nuori nainen ja nuori mies. Helsinki: SKS.

Kurki, Tuulikki. 2002. Heikki Meriläinen ja keskusteluja kansanperinteestä. Helsinki: SKS.

Kuusi, Matti. 1985 (1961). Lintuelegikko. Teoksessa Matti Kuusi: Perisuomalaista ja kansainvälistä. Helsinki: SKS.

Kuusi, Matti. 1970. Anni Lehtosen runousoppi. Virittäjä 74 (2), 293-303.

Kuusi, Matti. 1983. Maria Luukan laulut ja loitsut. Tutkimus läntisimmän Inkerin suomalaisperinteestä. Helsinki: SKS.

Lehtonen, Mikko. 1994. Kyklooppi ja kojootti. Subjekti 1600-1900 -lukujen kulttuuri ja kirjallisuusteorioissa. Tampere: Vastapaino.

Pentikäinen, Juha. 1971. Marina Takalon uskonto. Uskontoantropologinen tutkimus. Helsinki: SKS.

Pentikäinen, Juha. 1978. Oral Repertoire and World View. An Anthropological Study of Marina Takalo's Life History. Helsinki: Suomalainen tiedeakatemia.

Pentikäinen, Juha. 2010. Marina Takalo. Runonlaulaja ja näkijä. Helsinki: SKS.

Saarinen, Tuija. 2003. Poikkeusyksilö ja kyläyhteisö. Tutkimus Heikan Jussin (Juho Mäkäräisen) elämästä ja huumorista. Helsinki: SKS.

Seppä, Tiina. 2015. Kohtaamisia menneen kanssa. Tutkimus kansanrunoaineistojen synnystä ja myöhemmistä tulkinnoista. Joensuu: SKTS.

Sihvola, Juha. 2000. Anakronismi ja sen välttäminen. Teoksessa Pauli Kettunen, Auli Kultanen, Timo Soikkanen (toim.): Jäljillä. Kirjoituksia historian ongelmista. Osa 1. Turku: Turun Yliopisto.

Tarkka, Lotte. 2005. Rajarahvaan laulu. Tutkimus Vuokkiniemen kalevalamittaisesta runokulttuurista 1821-1921. Helsinki: SKS.

Timonen, Senni. 2004. Minä, tila, tunne. Näkökulmia kalevalamittaiseen kansanlyriikkaan. Helsinki: SKS.

Wagner, Roy. 1975 (2016). The Invention of Culture. Englewood Cliffs, N.J.: Prentice-Hall.

Seppo Knuuttila on perinteentutkimuksen emeritusprofessori ja Helmi Järviluoman työtoveri Itä-Suomen yliopistosta.

Elore liittyy merkkipäiväonnitteluihin! 